\title{
Fruit Fly, Anastrepha nigrifascia Stone (Insecta: Diptera: Tephritidae) ${ }^{1}$
}

H. V. Weems, Jr. ${ }^{2}$

\section{Introduction}

Anastrepha nigrifascia Stone is one of six species of fruit flies of the genus Anastrepha which occur in Florida or which have been established in Florida at some time. This species appears to have a very restricted distribution, occurring only in the Florida Keys of Monroe County. It seldom has been collected and is not considered to be of economic importance. Trap collection records indicate that it probably occurs in the adult stage throughout the year, although the heaviest populations appear to be during April-May. Populations during recent years appear to be near the threshold level, as no specimens have been collected since one was trapped at Key West on 1 June 1960 and another at the U.S. Naval Base at Key West on 10 May 1962.

\section{Distribution}

Florida Keys from Key Largo Key to Key West. The holotype female was trapped 21 May 1935 by G.B. Merrill on Big Pine Key.

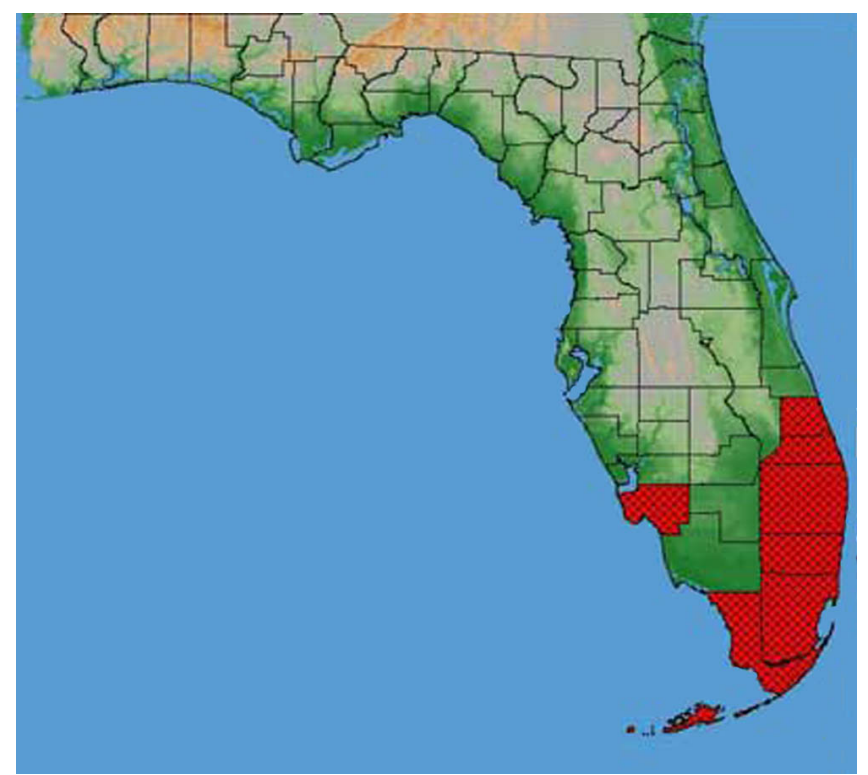

Figure 1. Distribution of the fruit fly, Anastrepha nigrifascia Stone, in Florida. Credits: G.J. Steck and B.D. Sutton, Division of Plant Industry

\section{Life History}

The life history of Anastrepha nigrifascia has not been ascertained, although adults have been reared several times from the fruit of Achras zapota

\footnotetext{
1. This document is EENY-262 (originally published as DPI Entomology Circular 66), one of a series of Featured Creatures from the Entomology and Nematology Department, Florida Cooperative Extension Service, Institute of Food and Agricultural Sciences, University of Florida. Published: January 2002. This document is also available on Featured Creatures Website at http://creatures.ifas.ufl.edu. Please visit the EDIS Website at http://edis.ifas.ufl.edu. Additional information on these organisms, including many color photographs, is available at the Entomology and Nematology Department website at http://entnemdept.ifas.ufl.edu/.

2. H. V. Weems, Jr., Florida Department of Agriculture and Consumer Services, Division of Plant Industry.
} 
(sapodilla) and Mimusops emarginata (wild- dilly or wild-sapodilla).

\section{Identification}

Small yellowish fruit fly, somewhat larger than a house fly, with rather long, patterned wings. $A$. nigrifascia can be distinguished from other species of Anastrepha which have been recorded for Florida by the presence of a narrow, transverse, dark brown band across the posterior of the mesoscutum at the base of the scutellum and by the ovipositor of the female, the tip of which is tapered and unserrated. Head yellow with frontal bristles and ocellar triangle black; antenna yellow, arista yellowish basally becoming brownish distally. Mesonotum mostly brownish yellow, scutellum yellow, macrochaetae black; pile yellow brown. The wing pattern is partly yellowish, partly brownish infuscated, and is somewhat variable. In some specimens the inverted $\mathrm{V}$ band is connected at its apex with the $S$ band on the anterior portion of the wing, while in others the inverted $\mathrm{V}$ band is incomplete with the distal arm of the $\mathrm{V}$ connected anteriorly to the $\mathrm{S}$ band and the proximal arm of the $\mathrm{V}$ constricted or separated in cell R5. Legs yellow.

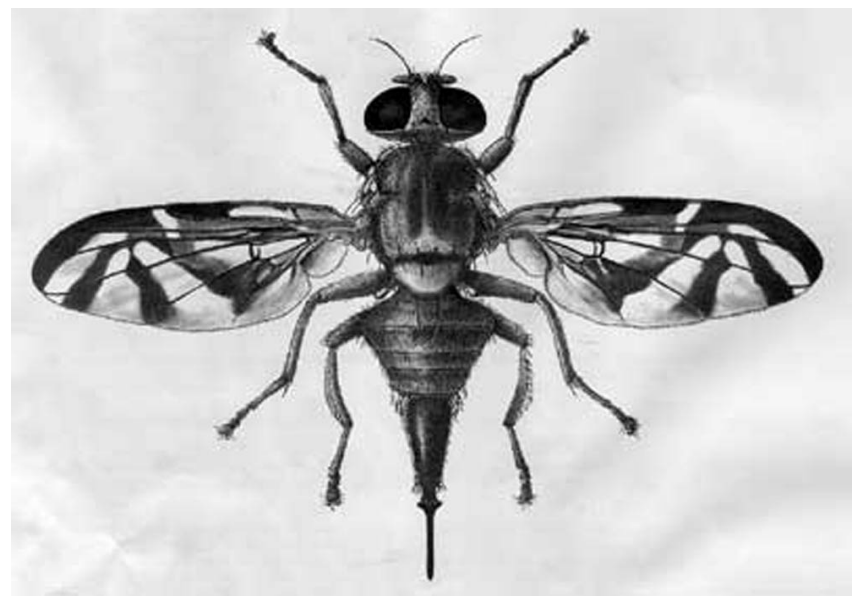

Figure 2. Adult female Anastrepha nigrifascia Stone. Credits: Division of Plant Industry

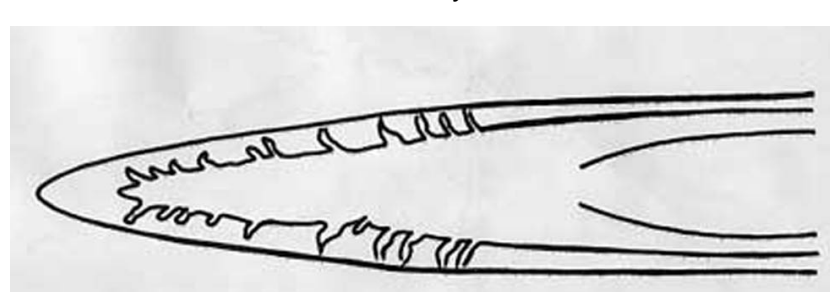

Figure 3. Ovipositor tip. Credits: Division of Plant Industry

\section{Hosts}

Achras zapota (sapodilla) and Mimusops emarginata (wild-dilly or wild-sapodilla).

\section{Selected References}

State Plant Board of Florida Eleventh Biennial Report for the period July 1, 1934-June 30, 1936. Jan. 1937. p. 21. Anastrepha sp. "W," Brown.

Stone A. 1942. The fruit flies of the genus Anastrepha. U.S. Department of Agriculture Miscellaneous Publication No. 439, Washington, DC. $112 \mathrm{p}$.

White IM, Elson-Harris MM. 1994. Fruit Flies of Economic Significance: Their Identification and Bionomics. CAB International. Oxon, UK. 601 p. 